\title{
Utilization of coal fly ash and municipal sewage sludge in agriculture and for reconstruction of soils in disturbed lands: results of case studies from Greece and China
}

\author{
Christos D. Tsadilas ${ }^{1} \cdot{\text { Zhenqi } \mathrm{Hu}^{2} \cdot{\text { Yinli } \mathrm{Bi}^{2}}^{2} \text { Thomai Nikoli }}^{1}$
}

Received: 14 November 2017/Revised: 25 February 2018/Accepted: 20 March 2018/Published online: 16 April 2018

(C) The Author(s) 2018

\begin{abstract}
Coal fly ash (CFA) and municipal sewage sludge (MSS) management is a great concern worldwide. An alternative gaining high interest, is their use in agriculture and for reclamation of degraded lands. The purpose of this paper was to present very briefly the results of some case studies carried out in China and Greece related to land reclamation and agricultural use of CFA and MSS separately or combined. An experiment in Platanoulia area, central Greece showed clearly that CFA applied together with MSS at appropriate rates increased substantially wheat grain and biomass yield and improved soil quality (increased soil $\mathrm{pH}$, organic matter content, total nitrogen, available $\mathrm{P}$ and boron). In a long-term experiment carried out in Huaibei city, Anhui province, China with a reconstructed soil in a subsided land by using CFA, it was found that physicochemical characteristics (infiltration rate, bulk density, total nitrogen, available P and extractable K) tended to be improved over time. In another experiment in Rodia area central Greece, MSS application improved soil quality of limestone mining spoils from bauxite mining activities. Several other experiments with MSS in Greece showed a clear positive effect on cotton and maize yield and on soil quality.
\end{abstract}

Keywords Coal fly ash $\cdot$ Municipal sewage sludge $\cdot$ Soil quality $\cdot$ Land reclamation

\section{Introduction}

Coal fly ash (CFA) is the finer ash produced in coal-fired power station, collected by using electrostatic precipitators. It comprises about $85 \%$ of the total ash produced. In terms of their potential to neutralize acidity, fly ashes can be broadly grouped into two classes: a) class $\mathrm{C}$ (produced by lignite and sub-bituminous coal) which is high in $\mathrm{CaO}$ content (>20\%), alkaline, and contains crystalline compounds, but low in silica and b) class $F$ (produced by

Christos D. Tsadilas

christotsadilas@gmail.com

1 Institute of Industrial and Forage Crops, Hellenic Agricultural Organization "DEMETER", 1 Theophrastos Street, 41335 Larissa, Greece

2 Institute of Land Reclamation and Ecological Restoration, China University of Mining and Technology, D11 Xueyuan Road, Haidian District, Beijing 100083, China bituminous and anthracite) with modest content of $\mathrm{CaO}$ $(<20 \%)$, lower proportions of crystalline components, and pozzolanic properties. Since the total amount of CFA produced worldwide annually is huge, amounting to about 750 million ton (Shaheen et al. 2014), its safe management is of high importance. Some properties of CFA both physical and chemical are interesting from an agronomic point of view and thus CFA in some cases may be used as a soil amendment (Yunusa et al. 2012). Municipal sewage sludge (MSS) is the byproduct (liquid or solid) resulted from the biological treatment of domestic wastes. Based on its management MSS may be considered as "waste" and it is land filled or incinerated or as a byproduct and may be applied in the soils. In the later case MSS is also called biosolid.

Coal fly ash utilization options include wasteland reclamation (for improving nutrients' conditions and promoting revegetation of disturbed/degraded lands), agriculture (for improving soil $\mathrm{pH}$, aeration, percolation, providing nutrients, and enhancing growth and yield), 
waste stabilization (by increasing adsorption of metals, color from waste water, by reducing of pathogens and odor from sludge, and by neutralizing of acid mine drainage) and bricks construction, supplement of cements/concrete, roads and embankments construction, and production of new products such as zeolites, ceramic filters etc. (Malik and Thapliyal 2009). CFA use in agriculture has no in all cases beneficial effects. Constraints related to agricultural use of CFA are referred to the content of inert material that may reduce water holding capacity, and the usually high heavy metal content (Malik and Thapliyal 2009), and organic pollutants (Sahu et al. 2009).

The properties of MSS which are significant when we use it in agriculture as soil amendment are physical (solid content, organic matter content), chemical $(\mathrm{pH}$, soluble salts, plant nutrients, trace elements, and organic chemicals) and biological (pathogens such as viruses, bacteria, protozoa, helminthes etc.).

The purpose of the present paper is to summarize the experimental results of some case studies carried out in Greece and China, aiming at using CFA and MSS as amendments of agricultural soils, for reclamation of disturbed land and reconstruction of soils in disturbed land due to mining activities.

\section{Experiments}

\subsection{Some research results of CFA and MSS use in soil and land of Greece and China}

\subsubsection{Concurrent use of CFA and MSS}

In a 2 years field experiment carried out in a strongly acid Typic Haploxeralf in Platanoulia area, central Greece, the influence of concurrent use of CFA and MSS on wheat grain and biomass yield and soil quality was investigated (Fig. 1). Soil pH was 4.75-5.25, soil texture was loamy and the organic matter content was $1.61 \%$. Details on the experimental design, amounts of CFA and SS applied, and cultivation practices are described by Tsadilas et al. (2014). The results obtained were very encouraging. Compared to control (no CFA, no MSS, no inorganic fertilizers), inorganic fertilization without CFA and MSS increased grain yield by $23 \%$. In the treatment that included inorganic fertilization plus CFA (220 ton/ha), grain yield increased by $71 \%$. In the treatments that included CFA and MSS, grain yield increased by the same percentage like in the treatment that included inorganic fertilization plus CFA. Similar results to grain yield were obtained for total biomass. Soil $\mathrm{pH}$ increased above $7.0(7.15-7.52)$ in the treatments that included CFA, organic matter increased up to $3.30 \%$ in the treatment that the highest rate of MSS was
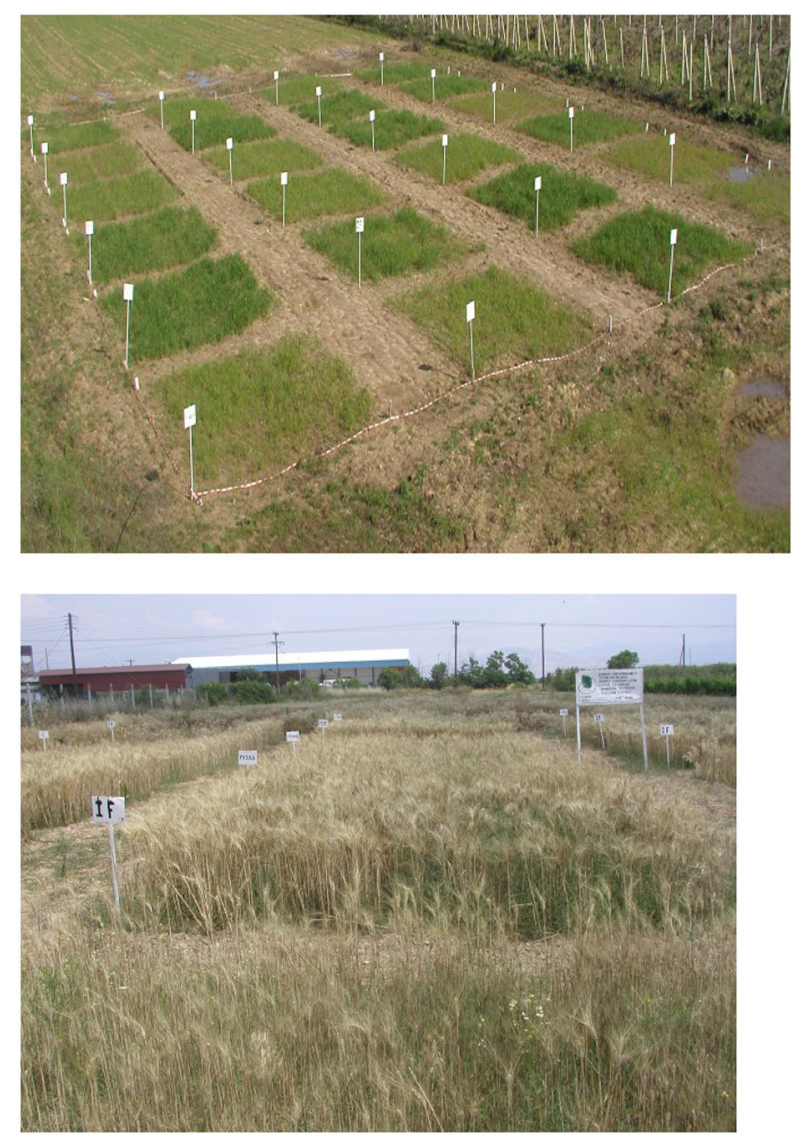

Fig. 1 Experiment in Platanoulia area, central Greece of concurrent application of CFA and MSS with wheat in different growth stages

applied. Electrical conductivity increased but at levels not harmful to salt tolerant crops (from 127 in the control to 257 in the treatment with the highest CFA and MSS rates). Total $\mathrm{N}$ content followed the trend of organic matter content, and available $\mathrm{P}$ increased from 18.25 in the control up to $51.7 \mathrm{mg} / \mathrm{kg}$ in the treatment with the highest MSS rate. Extractable $\mathrm{K}$ and $\mathrm{Mg}$ were not significantly affected but available boron increased from 0.77 to $1.70 \mathrm{mg} \mathrm{B} \mathrm{kg}^{-1}$ due to both CFA and MSS application. These B concentrations are not harmful to most of the extensive crops cultivate in the area such as wheat, maize and cotton. Zinc and $\mathrm{Pb}$ concentrations at both available and total forms increased, but available $\mathrm{Mn}$ and $\mathrm{Ni}$ forms decreased. The increase in total $\mathrm{Zn}$ and $\mathrm{Pb}$ was not above the permissible levels. These results show clearly the beneficial effect of alkaline CFA use in strongly acid soils.

\subsection{CFA use as filling material for reconstructed soils in subsided coal mined land}

In a long-term experiment carried out in Huaibei city, Anhui province, China (altitude 24-34 m above sea level, mean annual precipitation 500-900 mm, 
evapotranspiration $1800-1900 \mathrm{~mm}$, main crops wheat, corn, rice and soya), the usefulness of CFA as filling material for soil reconstruction in a subsided area due to coal mine was investigated. Soil was reconstructed by creating layers including $0-20 \mathrm{~cm}$ soil, $20-30 \mathrm{~cm}$ soil, 30-40 cm CFA, 40-60 cm CFA, 60-80 cm CFA (Fig. 2). The soil treatments were control (natural soil), soil reconstructed 1 year ago, 4 years ago, 8 years ago and 12 years ago, respectively. The results showed that in reconstructed soils, infiltration rate was less than the natural soil but tended to increase. The same stood also for nutrients concentration (total nitrogen, available $\mathrm{P}$ and extractable K). In general, all the properties of the retrieved soils were worse than the natural soil but they tended to be improved with time.

In the frame of the same research, a laboratory experiment was conducted to investigate the possibility of toxic substances leaching. In plastic columns $50 \times 70 \mathrm{~cm}$, various mixtures of CFA and soil and CFA and coal wastes from Pingdingshan, Henan Province, China, were put and flushed with deionized water. In the effluents, heavy metal concentrations were determined with ICP. The results showed that among the strongest leached elements were $\mathrm{B}$, $\mathrm{K}, \mathrm{Mo}, \mathrm{Cr}$ and $\mathrm{P}, \mathrm{As}, \mathrm{Cu}, \mathrm{Ni}, \mathrm{Fe}, \mathrm{Co}, \mathrm{Cd}$, and $\mathrm{Pb}$. In another experiment aiming at the investigation of Mycorrhizae (G. mosseae $\kappa \alpha_{l}$ G. Versiforme), effects in reconstructed soils using CFA and a calcareous soil from Pingdingshan, Henan Province was mixed with CFA in different ratios and planted with corn. After 8 weeks, the plants were harvested and biomass yield as well soil properties were determined. The results showed that Mycorrhizae enhanced plant growth obviously due to the increase of nutrients release (Tsadilas 2003).

\subsection{MSS use for reclaiming a mined land}

In an experiment conducted on a mined land located in the Rodia area of Parnassos mountain central Greece, the effects of the application of MSS on the physicochemical characteristics of limestone mining spoils from bauxite mining activities, was investigated. MSS derived from the treatment plant of the city of Karditsa, central Greece with pH 6.45 , organic matter $40 \%$, and heavy metal concentration below the limits imposed by the European legislation (Directive 86/278). The treatments included application of different amounts of MSS (0, 40, 80 and 120 ton dry sewage/ha, each one replicated 3 times in a complete randomized block design) and planted with grass and forest plants. Lysimeters were also used for studying possible leaching of pollutants (Fig. 3). The results showed that MSS applied in the experiment significantly improved soil properties of the mined land i.e. increase in organic matter content, available phosphorus, extractable potassium and magnesium, DTPA extractable copper, and zinc. However, MSS application decreased soil $\mathrm{pH}$ and increased cadmium and lead but they remained close to the background levels in the area. In addition, a leaching of $\mathrm{Cu}$, $\mathrm{Ni}, \mathrm{Mn}$, and $\mathrm{Cr}$ recorded soon after sewage sludge application (Tantos et al. 2006).

Similar results of the influence of MSS application in mined lands were reported by others. Brofas and Varelides (1997) used sewage sludge for improvement of calcareous bauxite mining spoils with application of $0,40,80$ and 120
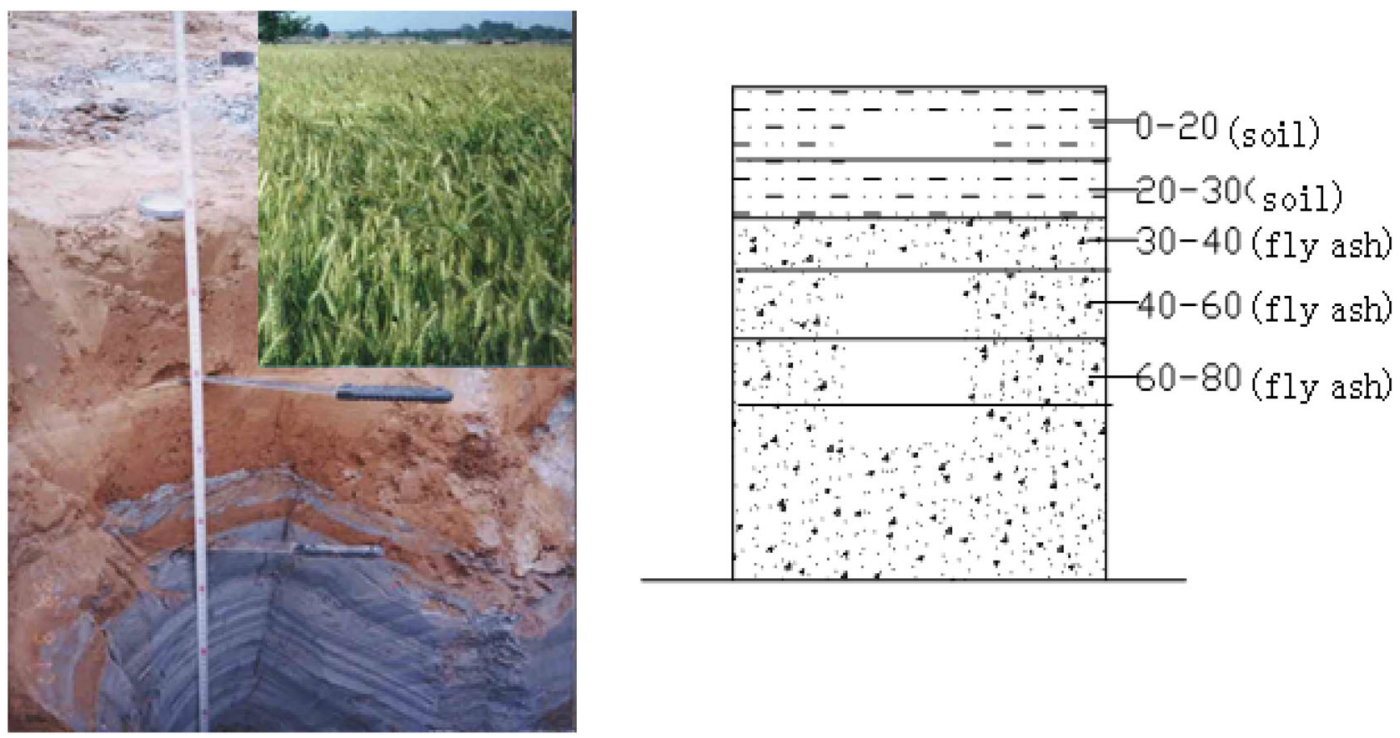

Fig. 2 Profile of reconstructed soil with CFA at Pingdingshan, Henan Province, China (in the upper right side of the picture wheat crop on the reconstructed soil) 


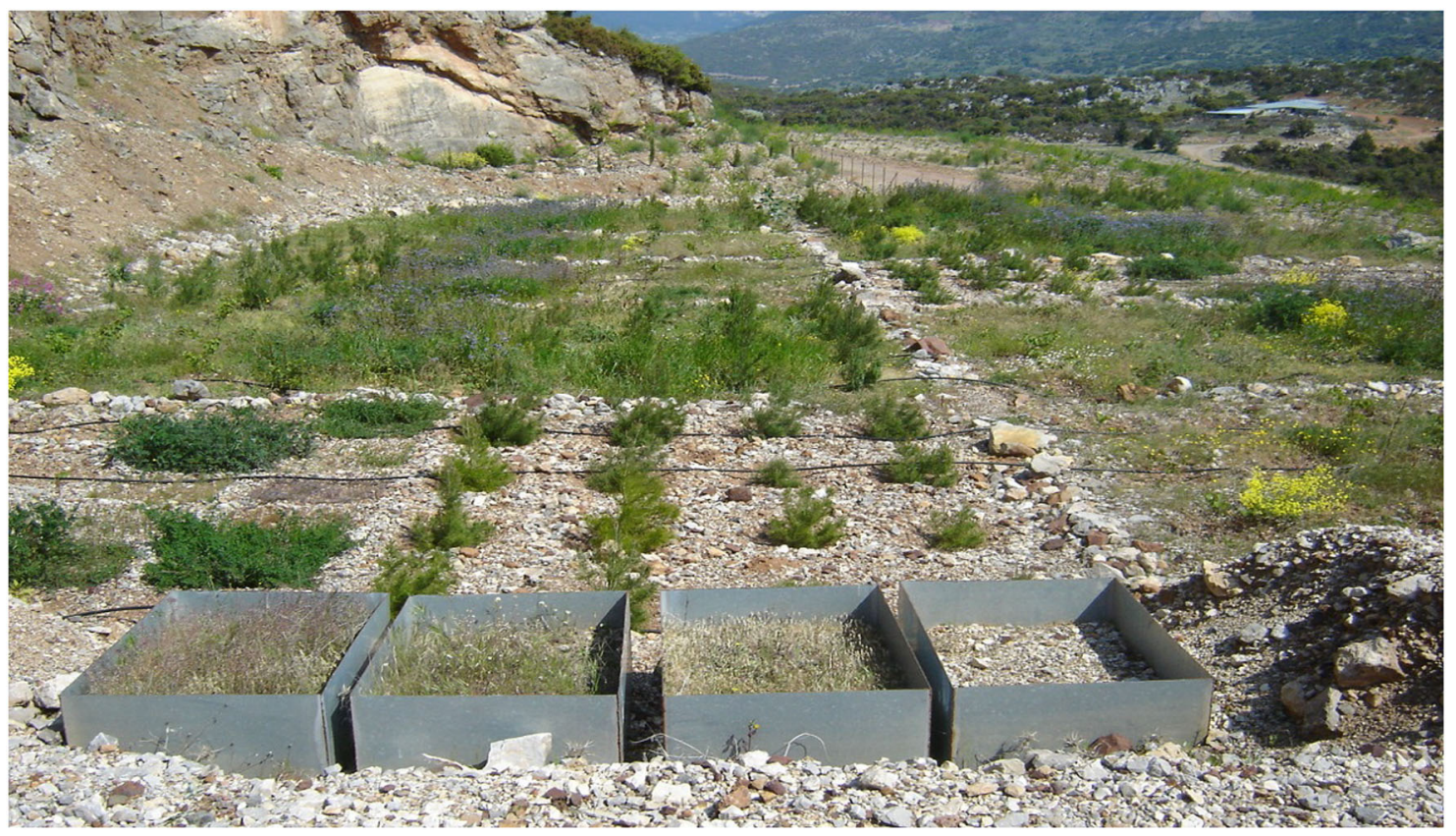

Fig. 3 Experiment with sewage sludge application on limestone mining spoils from bauxite mining activities in Rodia area, central Greece

tones dry weight per hectare. They found that significant increase of organic matter, $\mathrm{N}, \mathrm{P}, \mathrm{Ca}, \mathrm{K}, \mathrm{Mg}$, and CEC resulted from MSS application. In addition, $\mathrm{pH}$ decreased and heavy metals $\mathrm{Pb}, \mathrm{Cu}, \mathrm{Zn}$ and $\mathrm{Mn}$ increased, but their concentrations were within the range of natural soils occurrence. Water holding capacity and available spoil moisture were significantly increased. The number of the plants per square meter, above ground biomass yield and canopy cover were also significantly improved by MSS application. Brofas et al. (2000), in a similar field experiment on calcareous bauxite mine spoils with dried aerobically digested sewage sludge applied at seven rates $(0$, $10,20,40,60,80$ and $120 \mathrm{Mg} / \mathrm{ha}$ ), found that MSS significantly increased the available water capacity, concentrations of organic matter, total $\mathrm{N}$, extractable $\mathrm{P}$ (Olsen), exchangeable $\mathrm{Mg}^{2+}$, and DTPA-extractable $\mathrm{Cu}, \mathrm{Mn}, \mathrm{Zn}$, and $\mathrm{Pb}$ of mine spoils. Total $\mathrm{N}$ and extractable $\mathrm{P}$ concentrations decreased over time after sludge application. Plant biomass, plant density, and foliar cover significantly increased with treatment rates in the first and fourth growing seasons but decreased over time. Fiddleneck and burner were the species favored by the high rates of sludge application.

\subsection{MSS use as soil amendment of agricultural soils}

During the last 15 years a series of experiments were established in different representative soils of central Greece, aiming at the study of the effect of MSS use in agricultural soils and crops, following the legislative rules on the agricultural use of sewage sludge (Directive
86/278). Starting with pot experiments and continuing with repeated field experiments as well as pilot areas, a clear knowledge was obtained on the effects of MSS in agricultural soils and crops. Working with MSS of the city of Larissa, central Greece by using representative acid and alkaline soils and wheat plants, it was found that MSS significantly increase the $\mathrm{pH}$ of acidic soils and decrease the $\mathrm{pH}$ of alkaline soils, showing a buffering effect on soil $\mathrm{pH}$. Organic matter and electrical conductivity increased and the same stood also for available phosphorus and the essential micronutrients zinc $(\mathrm{Zn})$ and copper $(\mathrm{Cu})$ (Tsadilas et al. 1995). After this preliminary study, a series of experiments were established in the field with different crops such as wheat, corn, and cotton. In a 3 years field experiment with MSS of the city of Volos, central Greece the effect of MSS on cotton yield and soil quality was studied. The experimentation (Fig. 4) included a gradual increase in MSS rate of 10, 30, and 50 ton/ha dry MSS and two controls (one soil without any amendment and the other soil fertilized with the conventional rates of the fertilizers used in the area). The results confirmed that MSS is an effective soil amendment since due to its application, seed cotton yield increased in the first year by $14 \%-18 \%$, in the second year by $5 \%-19 \%$ and in the third year by $14 \%-36 \%$, compared to the control without any amendment. In most of the cases, the higher rates of MSS increased cotton yield more than the inorganic fertilizers, indicating that MSS may completely substitute inorganic fertilization, reducing thus substantially the cost of production of cotton (Samaras et al. 2007). At the same time soil quality, especially its dynamic part, was significantly 


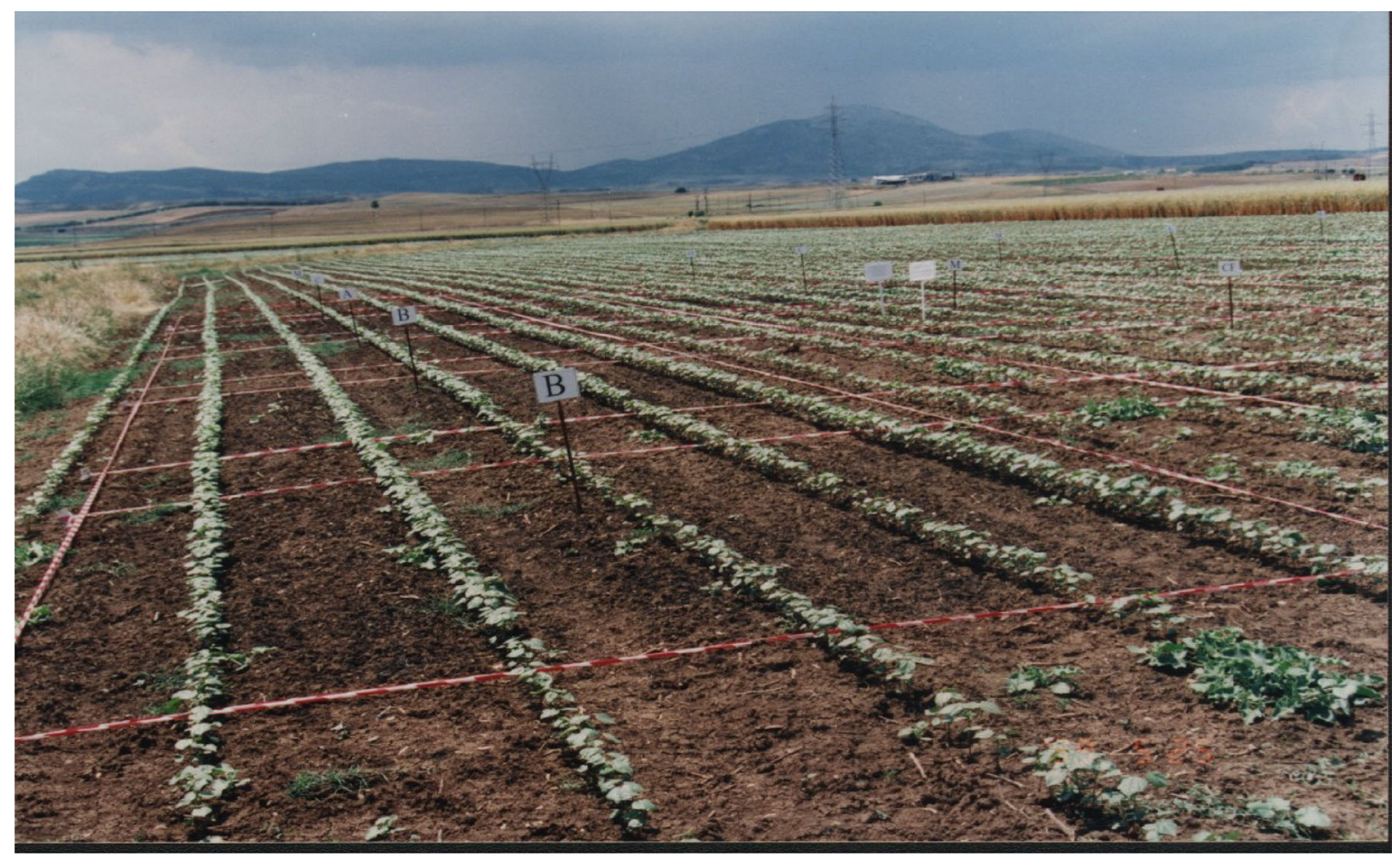

Fig. 4 Experiment with sewage sludge application in cotton crop in Magnesia area, central Greece

improved or not affected. Soil pH decreased by only 0.2 units due to mineralization of organic matter. Electrical conductivity slightly increased from 183 to $278 \mu \mathrm{mhos} / \mathrm{cm}$ in the surface soil (0-30 cm) and from 185 to $301 \mu \mathrm{mhos} /$ $\mathrm{cm}$ in the subsurface soil $(30-60 \mathrm{~cm})$. These values are considered quite low to restrict plant growth. Organic matter increased from $2.57 \%$ to $3.57 \%$ in the treatment with the 50 ton/ha dry MSS. The amount of total $\mathrm{N}$ added through the SS was estimated to be $675 \mathrm{~kg} \mathrm{~N} / \mathrm{ha}$ or about $135 \mathrm{~kg}$ available $\mathrm{N} / \mathrm{ha}$. This amount of $\mathrm{N}$ completely satisfies $\mathrm{N}$ cotton needs. Available $\mathrm{P}$ also increased significantly, but extractable $\mathrm{K}$ was not significantly affected.

\section{Conclusions}

Coal fly ash and municipal sewage sludge separately or together may be used for reclamation of disturbed lands due to mining activities and as soil amendments in agricultural soils. This management looks to be among the most beneficial and environmentally sustainable strategies.

Open Access This article is distributed under the terms of the Creative Commons Attribution 4.0 International License (http://crea tivecommons.org/licenses/by/4.0/), which permits unrestricted use, distribution, and reproduction in any medium, provided you give appropriate credit to the original author(s) and the source, provide a link to the Creative Commons license, and indicate if changes were made.

\section{References}

Brofas G, Varelides C (1997) Results of the use of sewage sludge for improvement of calcareous mining spoils. Int J Surf Min Reclam Environ 11(4): 163-167

Brofas G, Michopoulos P, Alifragis D (2000) Sewage sludge as an amendment for calcareous bauxite mine spoils reclamation. J Environ Qual 29(3):811-816

Malik A, Thapliyal A (2009) Eco-friendly fly ash utilization: potential for land application. Crit Rev Environ Sci Technol 39:333-366

Sahu SK, Bhangare RC, Ajmal PY, Sharma S, Pandit GG, Puranik VD (2009) Characterization and quantification of persistent organic pollutants in fly ash from coal fueled thermal power stations in India. Microchem J 92:92-96

Samaras V, Tsadilas C, Stamatiadis S (2007) Effects of repeated application of municipal sewage sludge on soil fertility, cotton yield, and nitrate leaching. Agron J 100:477-483

Shaheen SM, Hooda PS, Tsadilas CD (2014) Opportunities and challenges in the use of coal fly ash for soil improvements-A review. J Environ Manag 145:249-267

Tantos V, Tsadilas C, Mantakas G, Papadopoulos S, Tsagari K (2006) The use of municipal sewage sludge for reclamation of lands disturbed by mining activities. In: Proceedings of the 11th PanHellenic soil science conference, October 4-7, 2006, Arta, Greece (in Greek with summary in English), pp 515-524

Tsadilas C (2003) Influence of fly ash from coal combustion and domestic sewage sludge on soil quality. Final report of the bilateral research project between China and Greece. National Agricultural Research Foundation, Institute of Soil Mapping and Classification (in Greek with summary in English)

Tsadilas CD, Matsi T, Barbayiannis N, Dimoyiannis D (1995) The influence of sewage sludge application on soil properties and on the distribution and availability of heavy metal fractions. Commun Soil Sci Plant Anal 26(15-16):2603-2619 
Tsadilas C, Samaras V, Evangelou E, Shaheen S (2014) Influence of fly ash and sewage sludge application on wheat biomass production, nutrients availability, and soil properties. Int J Coal Sci Technol 1(2):221-226
Yunusa IAM, Loganathan P, Nissanka SP, Manooharan V, Burchett MD, Skilbeck CG, Eamus D (2012) Application of coal fly ash in agriculture: a strategic perspective. Crit Rev Environ Sci Technol 42:559-600 